\title{
Biological and Serological Identification of Barley Yellow Dwarf Virus (BYDV) and Its Distribution in Iraq
}

\author{
Rakib A. Al-Ani, Mustafa A. Adhab, Muthannah A. El-Muadhidi \& Maadh A. Al-Fahad \\ Plant Protection Department, College of Agriculture, University of Baghdad, Iraq \\ E-mail: maa_adhab@hotmail.com
}

$\begin{array}{lc}\text { Received: May 9, } 2011 \quad \text { Accepted: May 27, } 2011 \quad \text { Online Published: December 21, } 2011 \\ \text { doi:10.5539/jas.v4n2p39 } & \text { URL: http://dx.doi.org/10.5539/jas.v4n2p39 }\end{array}$

\begin{abstract}
Barley yellow dwarf virus (BYDV) was identified by means of symptoms on indicator plants, transmission by aphids, and serological characteristics. Symptoms of yellowing and stunting were appeared on leaf tips of Hordium vulgare, Triticum aestivum, and Avena fatua accompanied by stem stunting. Four species of aphids, Rhopalosiphum maidis, R. padi, Macrosiphum avenae, and Schizaphis graminum were found vectoring the virus. Extracts from wheat and barley plants showing yellowing and stunting were reacted positively with polyclonal anti-BYDV antiserum in DAS-ELISA. Most of samples that gave positive reactions by ELISA gave positive reactions with tissue blot immunoassay (TBIA). Higher incidence of BYDV was found in the northern parts of Iraq. Several economical and weed plants, collected from wheat and barley fields and vicinity sites have been found to harbor the virus. These hosts may acts as virus reservoir transmitting to wheat and barley plants by aphids.
\end{abstract}

Keywords: BYDV, Triticum aestivum, Hordium vulgare, TBIA, DAS-ELISA, Aphid transmission

\section{Introduction}

Barley yellow dwarf virus (BYDV), a species of luteovirus group is the most widely distributed and most destructive virus on cereal crops in the world (Lister and Ranieri, 1995; Miller et al., 2002; Kennedy and Connery, 2005).

Symptoms in Triticum aestivum were not always clear and characterized by stunting with yield losses (Irwin and Thresh 1990). On oat the symptoms yellowish green blotches near the leaf tip. These blotches enlarge, merge, and turn to red, purple, brown, or yellow-orange. The yellowish-green area extend to lower parts of the leaf and the leaves may curl inward (D’Arcy 1995). In Hordium vulgare the most characteristic symptoms are dwarfing with brilliant yellow color on the leaves which extend from the tip toward the basal parts (Rochow et al., 1996). BYDV cause dwarfing with yellowing or reddening on corn (Rochow et al., 1996).

The virus is transmitted by several species of aphids in a persistent manner, including Rhopalosiphum padi, which is the most efficient. Other species of aphids such as Schizaphis graminum, Macrosiphum avenae, $R$. maidis were also reported vectoring the virus. The aphids can acquire the virus by feeding on a diseased plant for a minimum of $30 \mathrm{~min}$ and the viruliferous aphids are capable of transmitting the virus, after an incubation period of $12 \mathrm{hrs}$ to 4 days. The virus is not transmitted by eggs, and does not replicate in the vector. BYDV strains have been differentiated according to their aphid vectors (Halbert et al., 1992; Olser et al., 1992; Sadeghi et al., 1997; Lucio-Zavaleta et al., 2001; Miller et al., 2002).

Different kinds of techniques have been used to detect BYDV. Double antibody sandwich-Enzyme linked immunosorbent assay (DAS-ELISA) is the most widely adopted using polyclonal antibodies (El-Zoubi et al., 1992; Klein and Lister, 1992; Makkouk and Comeau, 1994; Makkouk et al., 1994).

The objective of this study was to identify Barley yellow dwarf virus on $T$. aestivum and H. vulgare, determine its distribution at different sites in Iraq and test the ability of some aphid species to vector the virus.

\section{Materials and Methods}

Virus identification: The virus was identified biologically on test plants, serologically by Tissue blot immunoassay (TBIA) and double antibody sandwich enzyme-linked immunosorbent assay (DAS-ELISA), and aphid transmission. 
Virus source: Plants of T. aestivum and H. vulgare showing symptoms of yellowing and dwarfing suspected to be of Barley yellow dwarf virus (BYDV) were transplanted into plastic pots $(20 \times 30 \mathrm{~cm})$, containing mix soil, from different fields of T. aestivum and H. vulgare in Iraq during 2007-2008 and 2008-2009 growing seasons. The plants were maintained in insect protected cages $(36 \times 27 \times 53 \mathrm{~cm})$ in insect-proof glasshouse and used as virus source.

Data analysis: Samples of wheat and barley plants showing yellowing and stunting were randomize collected from different sites of Iraq. The virus was characterized by means of symptoms on indicator plants, serological techniques (DAS-ELISA and TBIA), and aphid transmission. The distribution of the virus in wheat and barley fields and its secondary hosts were also determined.

Test plants: Seeds of Hordeum vulgare, Avena fatua, T. aestivum, Zea mays, and Lolium temulentum test plants for BYDV (Brunt et al., 1996), were sown in pots $(20 \times 30 \mathrm{~cm})$ containing mix soil and peatmoss (1:1) in a glasshouse $\left(12-25{ }^{\circ} \mathrm{C}\right)$. The seedlings, at $2-4$ leaves stage, were transplanted to other pots $(10 \times 12 \mathrm{~cm})$ containing the same mix soil and sprayed with Benlate at $1 \mathrm{~g} / \mathrm{L}$ and Confidor at $1 \mathrm{~g} / \mathrm{L}$ to prevent fungi and insects.

Inoculation: Apterous of $M$. avenae, identified at Plant Protection Department, College of Agriculture, University of Baghdad, Iraq, were collected from $H$. vulgare and $T$. aestivum fields. The aphids were reared on $H$. vulgare healthy plants in protective cages, maintained in insect-proof glasshouse and routinely used in virus transmission. Groups of reared aphids were transferred onto infected plants (T. aestivum and $H$. vulgare) (10 aphids/plant) for $24 \mathrm{hrs}$. The viruliferous aphids were placed on the test plants at 4 leaves stage for $48 \mathrm{hrs}$. The plants were then sprayed by an insecticide to eliminate the aphids. The symptoms were evaluated after 4 weeks of inoculation. R. padi, R. maidis, and S. graminum, were also collected and tested for their ability to transmit the virus.

\section{Serological assays:}

Tissue blot immunoassay (TBIA): TBIA procedure was done according to Abouzid et al., (2002) with slight modification. A cross-section was made in the stem of infected and healthy plants with razor blade. The cut surface was firmly pressed on to the surface of nitrocellulose membrane $(0.45 \mu \mathrm{m})$ for several seconds. Blotted membranes were allowed to air dry and incubated in blocking buffer, phosphate buffer saline (PBS)(15 mM $\mathrm{KH}_{2} \mathrm{PO}_{4}, 20 \mathrm{mM} \mathrm{Na} 2 \mathrm{HPO}_{4}, 150 \mathrm{mM} \mathrm{NaCl}$ and $0.05 \%$ Tween-20), containing $5 \%$ powdered Skim milk for 15 min at room temperature in Petri dishes. The membranes were washed three times in PBS buffer containing $0.025 \%$ Tween-20 (PBST) and incubated with polyclonal antiserum to BYDV (1:500) for $1 \mathrm{hr}$ at room temperature. Membranes were then washed three times as before and incubated in alkaline phosphatase conjugated goat anti-rabbit IgG (1:2000) provided with Dr. Safa Kumari (Virology lab., ICARDA, Aleppo) at room temperature for $1 \mathrm{hr}$. The membranes were washed three times as previously and the conjugate was visualized by incubation in a substrate buffer (phosphate buffer) containing nitro blue tetrazolium (NBT) (750 $\mu \mathrm{g} / \mathrm{ml})$ and 5-bromo-4-chloro-3-indolyl phosphate (BCIP) $(500 \mu \mathrm{g} / \mathrm{ml})$ for $15 \mathrm{~min}$ at room temperature with continuous shaking. The reaction was stopped by washing the membranes by sterile distilled water. The immunological reactions were detected by naked eye or by dissecting microscope; violet to purple color indicates positive reaction.

Virus purification: T. aestivum and $H$. vulgare plants showing BYDV symptoms approximately, $250 \mathrm{~g}$, were ground by mortar and pestle in $0.1 \mathrm{M}$ phosphate buffer, $\mathrm{pH} 6.0$ containing $2 \%$ celluclast, $0.1 \%$ 2-mercaptoethanol, and $0.02 \% \mathrm{NaN}_{3}, 1: 3(\mathrm{~g} / \mathrm{ml})$. The extract was filtered through two layers of filter paper. Triton X-100 was added to the filtrate at $1 \%$ with agitation at room temperature for $3 \mathrm{hrs}$, then a mixture of chloform-butanol (1:1) was added at 6:1 (v:v) with agitation for $10 \mathrm{~min}$ at room temperature. The extract was centrifuged at $5000 \mathrm{rpm}$ for $30 \mathrm{~min}$ in (Sor) Hettich-Universal II. The virus was precipitated by $8 \%$ polyethylene glycol, $8000 \mathrm{MW}$, and $1 \% \mathrm{NaCl}$, and recuperated by centrifugation at $5000 \mathrm{rpm}$ for $30 \mathrm{~min}$. Virus pellets were suspended in $0.1 \mathrm{M}$ phosphate buffer $\mathrm{pH} 6.0$ containing $0.1 \%$ Triton X-100. The virus was separated by centrifugation in sucrose gradient $15-55 \%$ with reverse gradient of ammonium sulfate $55-15 \%$ at $5000 \mathrm{rpm}$ for 3 hrs. The band correspond to virus was carefully withdrawn from the gradient, diluted fivefold with phosphate buffer $0.1 \mathrm{M} \mathrm{pH} 7.5$ and centrifuged at $30000 \mathrm{rpm}$ for $3 \mathrm{hrs}$ in Beckman Ultracentrifuge - 35, using rotor - 30 . The purified virus was resuspended in small volume of phosphate buffer and used for rabbit immunization.

Immunization: Antibody to BYDV was prepared by 5 adminstrations, $1 \mathrm{ml}$ of the virus at $1 \mathrm{mg} / \mathrm{ml}$ weekly. The first two injections were intramuscularly emulsified with an equal volume of complete Freund's adjuvant, followed by three injections in the ear marginal vein without adjuvant. The blood was collected after 12 days of the last injection through the ear marginal vein in a beaker. The blood was held at room temperature for $2 \mathrm{hrs}$ for 
agglutination, and the serum was centrifuged at $5000 \mathrm{rpm}$ for $15 \mathrm{~min}$. The antiserum was purified and conjugated with alkaline phosphatase according to Clark and Adams (1977).

Virus survey: A survey was effectuated to 58 locations of $T$. aestivum and $H$. vulgare fields at the North, middle, and south of Iraq. Approximately 26150 plants from 520 fields were randomly collected, by walking a transect of the fields four times, at booting stage (from 41-49) according to Zadoks scale (Zadoks et al., 1974) during February to April of 2007-2008 and 2008-2009 growing seasons.

BYDV detection: BYDV was detected by DAS-ELISA and TBIA protocols.

DAS-ELISA: Young leaves were ground with a mortar and pestle in phosphatase buffer saline (PBS) pH 7.0, 1:10 (g/ml). The extracts were centrifuged at $5000 \mathrm{rpm}$ for $10 \mathrm{~min}$ and the supernatant was collected.

Anti-BYDV antiserum $(200 \mu \mathrm{l})$ diluted to $1: 1000$ with coating buffer $\left(35 \mathrm{mM} \mathrm{NaHCO}, 15 \mathrm{mM} \mathrm{Na}_{2} \mathrm{CO}_{3}, 0.2 \%\right.$ bovine serum albumin (BSA), pH 9.6), was loaded in each well of polystyrene ELISA plates. The plates were incubated at $37{ }^{\circ} \mathrm{C}$ for $4 \mathrm{hrs}$ and the wells were washed three times with phosphate buffer saline containing $0.05 \%$ Triton X-100. To each well, $200 \mu \mathrm{l}$ of plant extracts previously prepared was added and the plates were maintained at $4{ }^{\circ} \mathrm{C}$ overnight. The wells were washed three times as before and $200 \mu \mathrm{l}$ of anti-BYDV IgG conjugated with alkaline phosphatase (1:1000) in Enzyme-labeled buffer, $\mathrm{pH} 7.0$, was added to each well. After incubation at $37^{\circ} \mathrm{C}$ for $4 \mathrm{hrs}$ and washed three times, $200 \mu \mathrm{l}$ of substrate (p-nitrophenyl phosphate) at $1 \mathrm{mg} / \mathrm{ml}$ in $10 \%$ diethanolamine, $\mathrm{pH} 9.8$ was added to each well. The plates were maintained at room temperature for $1 \mathrm{hr}$ and the absorbances at $405 \mathrm{~nm}$ were recorded in ELISA-reader.

\section{Results}

Symptoms: The virus induced yellow-golden areas on leaves tips of Hordium vulgare 7 days after inoculation by $M$. avenae. These areas were extended toward the basal tissue, then to the entire plant accompanied by stunted growth. Similar symptoms were reported by Comeau et al., (1992) concerning BYDV on H. vulgare.

Faint light green-yellowish spots were developed on leaves tips of Avena fatua after 14 days of inoculation by $M$. avenae, extended gradually to other parts of the leaves which turned finally to yellow-orange, sometimes accompanied by leaf curling inward. Identical symptoms recorded following the methods of Comeau (1987), and time of symptoms development by Gill (1967) on oat plants inoculated by BYDV.

Yellowing symptoms were observed on $T$. aestivum after 7 days of virus inoculation accompanied by stem stunting after 14 days. These symptoms are similar to those reported by Reporton (1989) on triticum plants inoculated by BYDV.

No visible symptoms on leaves of $Z$. mays and L. temulentum were developed after 21 days of inoculation, but the virus was detected in the inoculated plants by serological TBIA test.

Insect transmission: Four species of aphids R. padi, M. avenae, R. maidis, and S. gramineum were found in $T$. aestivum and $H$. vulgare field capable of transmitting the virus as proved by development of typical yellowing on the inoculated T. aestivum and H. vulgare plants, which indicates that the virus is vectored by these species of aphids. The inoculated T. aestivum plants developed typical symptoms of BYDV after 9, 7, 16, 17 days of inoculations by the four species above with percentages of infection 73.4, 50.0, 26.6, and $43.5 \%$ respectively, while the symptoms took $6,6,12$, and 14 days to develop on $H$. vulgare with percentages of infections 100,60 , 36 , and $50 \%$ respectively (Table 1 ). These results indicate that $R$. padi is more efficient in vectoring the virus, followed by $M$. avenae, and $H$. vulgare is more susceptible host to the virus than T. aestivum.

Serological assays: Extracts from T. aestivum and $H$. vulgare plants showing yellowing and stunting collected from fields at different locations in Iraq, reacted positively with polyclonal anti-BYDV antiserum in DAS-ELISA. Most samples that gave positive reactions by ELISA, gave positive reaction with Tissue blot immunoassay (TBIA) as shown by intense purple staining on the nitrocellulose membrane blotted by stem cut surfaces. No reaction with extracts from healthy plants was observed (Fig. 1).

Virus survey: Remarkable differences in BYDV incidence between the different locations used for virus survey in Iraq were observed. The highest distribution of the disease were noted in the northern region of Ta'amim, Sulaimaniya, Erbil, Nineveh, and Dohuk provinces with disease incidences of 4, 3, 4.7, 11.5, and $5 \%$ on $T$. aestivum, 3.7, 4.8, 6.8, 14.4, and $8.3 \%$ on $H$. vulgare respectively. This was followed by middle region in Baghdad, Dayalah, Anbar, and Salah El-din provinces, with disease incidences of 4.4, 2.8, 0.0, and 3.4\% on $T$. aestivum, 5.2, 5.2, 1.4, and 3.7\% on $H$. vulgare respectively. The lowest disease incidence were found in southern region namely Basra, Missan, Thi-Qar, Wasit, Al-Muthanna, Al-Qadissiya, Babylon, Najaf, and 
Karbala provinces, with disease incidences of $0.0,0.0,0.0,1.6,0.0,0.0,1.7,1.6$, and 2.0\% on T. aestivum, 0.0 , $0.0,0.0,2.3,0.0,0.0,1.8,2.4$, and $2.5 \%$ on $H$. vulgare respectively in 2007-2008 growing season (Table 2).

Considerable increase in disease incidence values in 2008-2009 growing season was observed, 6.4, 6.2, 10.5, 17.5, and $12.3 \%$ on $T$. aestivum, $6.3,7.2,11.8,24$, and $13.7 \%$ on $H$. vulgare in North provinces, 8.5, 6.5, 2.0, and $5.4 \%$ on $T$. aestivum, 9.8, 7.2, 4.3, and $6.8 \%$ on $H$. vulgare in middle provinces, $0.0,0.0,0.0,3.4,0.0,3.0$, $4.0,5.2$, and $4 \%$ on $T$. aestivum, $0.0,0.4,0.4,4.6,0.0,3.5,4.9,5.7$, and $4.8 \%$ on $H$. vulgare in South provinces, for the same provinces above respectively (Table 3 ).

Variations in disease incidence between sites in the same province were also observed, with highest values in Nineveh provinces, 11.5 and $17.5 \%$ on T. aestivum, 14.4 and $24 \%$ on $H$. vulgare in northern region, followed by Baghdad province, 4.4 and $8.2 \%$ on $T$. aestivum, 5.2 and $9.8 \%$ on $H$. vulgare in middle region, and Najaf province, 1.6 and $5.2 \%$ on $T$. aestivum, 2.4 and 5.7\% on H. vulgare in southern region in 2007-2008 and 2008-2009 growing seasons respectively.

Secondary hosts of BYDV: Positive reaction between extracts from economic and weed plants, collected from T. aestivum and $H$. vulgare fields and from vicinity sites, and polyclonal anti-BYDV by TBIA protocol was developed. The percentage of infection among these hosts ranged from $26.7 \%$ in Phalaris minor to $66.7 \%$ in $\mathrm{A}$. fatua and Z. mays. Some of these plants were found to harbor the virus with unclear symptoms. These results indicate that these plants may serve as reservoirs for the virus (Table 4).

\section{Discussion}

The virus causing yellowing and dwarfing on T. aestivum and $H$. vulgare plants was considered as Barley yellow dwarf virus (BYDV) according to the symptoms shown on the indicator plants, the transmissibility by different species of aphids, and the positive reaction with serological TBIA, as shown by intense purple staining in the vascular bundles on nitrocellulose-membrane blotted by stem cut surface, using polyclonal anti-BYDV-PVA. No visible symptoms on $Z$. mays and L. temulentum were developed after 21 days of inoculation, although the virus was present in the plants as proved by TBIA. These results are in agreement with Osler et al., (1985), Brunt et al., (1996) in that BYDV infect maize plants without visible symptoms. Our results agreed also with Leather and Dixon (1981), and Fargetti et al., (1982), in that Lolium plants harbor the virus but showed no visible symptoms. These hosts may serve as virus reservoirs.

Several species of aphids were found able to transmit the virus, more efficiently by $R$. padi and $M$. avenae, less efficiently by $R$. maidis, and $S$. graminum. These results may indicate the existence of more than one isolate for the virus. Some previous studies reported that BYDV strains can be vectored with varying efficiency by different species of aphids (Sadighi et al., 1997; Lucio-Zavaleta et al., 2001).

The results of virus survey provide information about the distribution and epidemiology of BYDV at different locations in Iraq. The results showed that the virus exist in most of the fields used for the survey with higher incidence in northern parts (Nineveh). The variation in disease incidence between the locations may be due to; sowing date, field expansion, prevailing and movement of aphid population during the season, weather conditions, alternative and alternate hosts, $T$. aestivum and $H$. vulgare fields nearby. The report of Lucio-Zavaleta et al., (2001) indicated that the period September-October (sowing date of T. aestivum and H. vulgare) provide suitable environment for the alate of $P$. padi to acquire the virus from infected corn and migrating to emerging $T$. aestivum and $H$. vulgare plants. Other studies reported that the spread of BYDV early in the fall was due to the presence of corn plants and weed grass which act as virus source transmitted to $T$. aestivum and H. vulgare plants by alate aphids (El-Yamani, 1992; Irwin and Thresh, 1992; Van Reissen et al., 1998).

Results of serological assays showed that TBIA is more reliable and easy to carry out than ELISA in the field for detecting BYDV in $T$. aestivum and $H$. vulgare tissues. We found that TBIA is also sensitive as ELISA but unlike ELISA, it does not require sample extraction or sophisticated tools. It was shown that tissue-specificity varied among crops for reliable tissue in detecting viruses by TBIA (Jonson et al., 2007). In this study we have found that stem tissue was more efficient than other tissue in detecting BYDV. It was noted that some sample extracts that gave positive reaction with ELISA, failed to give reaction with TBIA, using anti-BYDV-PVA antiserum especially those from $H$. vulgare plants inoculated by $S$. gramineum that transmit BYDV-SGA (Irwin and Thresh, 1992). This finding support the conclusion mentioned above in this study that more than one strain may exist for BYDV in Iraq.

\section{Acknowledgment}


The authors wish to acknowledge Dr. Safa Kumari Virology lab., ICARDA, Aleppo, Syria for providing goat anti-rabbit IgG.

\section{References}

Abouzid A.M., Freitas-Astua J., Purcifull D.E., Polson J.E., Beckham K.A., Crawford W.E., Peterson M.A., Peyser B., Patte C., \& Hiebert E. (2002). Serological studies using polyclonal antisera prepared against the viral coat protein of four begomoviruses expressed in Escherichia coli. Plant Disease, 86, 1109-1114. http://dx.doi.org/10.1094/PDIS.2002.86.10.1109

Brunt A., Dallwitz M., Grabbs A., Watson L., \& Zurcher E. (1996). Plant virus-BYDV description lists from the ViDE database. Version $20^{\text {th }}$ August. URL.

Clark M.F., \& Adams A.N. (1977). Characteristics of the microplate method of enzyme-linked immunosorbent assay for the detection of Plant viruses. Journal of General Virology, 34, 475-483. http://dx.doi.org/10.1099/0022-1317-34-3-475

Comeau A. (1987). Effects of BYDV inoculation at antivirus dates for oats, barley, Triticum aestivum, rye and tritical. Phytoprotection, 68, 97-109.

Comeau A., Conin J., \& Cheour F. (1992). BYDV symptoms and Elisa data in relation to biomass and yield loss. In: BYDV in west Asia and North Africa. Comeau, A. and K. Makkouk(eds.). Sayce Publishing, Exeter, UK. P, 155-168.

D'Arcy C.J. (1995). Symptomatology and host range of barley yellow dwarf. Journal of Plant Pathology, 4, 9-28.

El-Yamani M., Makkouk K., Hafidi B., \& El-Kassemi K. (1992). Contribution to the study of BYDV in the Souss-massa region of Morocco. Phytopathologia Mediterranea, 31, 41-45.

El-Zoubi M., Almosa A., \& Skaria M. (1992). Studies on BYDV in cereal crop in Jordan. In: BYDV in west Asia and North Africa. Comeau, A. and K. Makkouk (eds.). Sayce Publishing, Exeter, UK. P, 91-102.

Fargette D., Lister R., \& Hood E. (1982). Grasses as a reservoir of BYDV in Indiana. Plant Disease, 66, 1041-1045. http://dx.doi.org/10.1094/PD-66-1041

Gill, C. (1967). Transmission of Barley yellow dwarf virus in isolate from Manitoba by five species of aphids. Phytopathology, 1, 713-718.

Halberd S.E., Connelly B.J., Lister R.M., Klein R.E., \& Bishop G.W. (1992). Vector specificity of Barley yellow dwarf virus serotypes variants in southwestern Idaho. Ann. Appl. Biol., 121, 123-132. http://dx.doi.org/10.1111/j.1744-7348.1992.tb03992.x

Irwin M.E., \& Thresh J.M. (1992). BYDV epidemiology: A study in ecological complexity. In: BYDV in west Asia and North Africa. Comeau, A. and K. Makkouk(eds.). Sayce Publishing, Exeter, UK. P, 3-30.

Irwin M.E., \& Thresh J.M. (1990). Epidemiology of barley yellow dwarf: A study of ecological complexity. Ann. Rev. Phytopathology, 28, 393-424. http://dx.doi.org/10.1146/annurev.py.28.090190.002141

Jonson G., Park J.C., Kim Y.K., Kim M.J., Lee M.J., Hyun J.N., \& Kim J.G. (2007). Direct stem blot immunoassay (DSBIA): a rapid reliable and economical detection technique suitable for testing large number of barley materials for field monitoring and resistance screening to Barley mild mosaic virus and Barley yellow mosaic virus. Plant Pathology Journal, 23, 260-265. http://dx.doi.org/10.5423/PPJ.2007.23.4.260

Kennedy T.F., \& Connery J. (2005). Grain yield reduction in spring barley due to Barley yellow dwarf virus and aphid feeding. Irish Journal of Agricultural and Food Research, 44, 111-128.

Klein R., \& Lister R. (1992). Advantages and limitation of some methods for BYDV detection and diagnosis. In: $B Y D V$ in west Asia and North Africa. Comeau, A. and K. Makkouk (eds.). Sayce Publishing, Exeter, UK. P, 169-176.

Leather S., \& Dixon A. (1981). The effect of cereal crop stage and feeding size on the reproductive activity of the bird cherry-out aphid, Rhopalosiphum padi. Ann. Appl. Biol., 97, 135-141. http://dx.doi.org/10.1111/j.1744-7348.1981.tb03006.x

Lister R.M., \& Ranieri R. (1995). Distribution and economic importance of barley yellow dwarf. pp. 29-53. In: Barley yellow dwarf (40 years in progress). D'Arcy, C.J. and P.A. Bumeft (eds.). The American Phytopathological Society. St. Paul. MN. 
Lucio-Zavaleta E., Smith D.M., \& Gray S.M. (2001). Variation in transmission efficiency among Barley yellow dwarf virus-RMV isolates and clones of the normally inefficient aphid vector Rhopalosiphum padi. Phytopathogy, 91, 792-796. http://dx.doi.org/10.1094/PHYTO.2001.91.8.792

Makkouk K., Comeau A., \& Pierre S.t. (1994). Screening for BYDV luteovirus resistance in barley on the basis of virus movement. J. Phytopathology, 141, 165-172. http://dx.doi.org/10.1111/j.1439-0434.1994.tb01458.x

Makkouk K., \& Comeau A. (1994). Evaluation of various methods for the detection of BYDV by the tissue-blot immunoassay and its use for virus detection in cereals inoculated at different growth stages. European J. of Plant Pathology, 100, 71-80. http://dx.doi.org/10.1007/BF01871967

Miller W.A., Liu S., \& Beckelt R. (2002). Barley yellow dwarf virus; Luteoviriae or Tombusviridae? Molecular Plant Pathology, 3(4), 177-188. http://dx.doi.org/10.1046/j.1364-3703.2002.00112.x

Osler R., Loi N., Lorenzeni C., Snidaro M., \& ReRafti E. (1985). BYDV infection in maize in brods and hybrids in northern Italy. Maydica, 30, 285-290.

Osler R., Loi N., \& Pertot I. (1992). Characterization of a new RMV-like strain of BYDV by aphid transmission. Riv. Pathol. Veg., 2, 33-38.

Reporton, C. (1989). BYDV disease of small grains. University of Illinois. Report on Plant Disease. RPD. 101.

Rochow W.F., Sward R.J., \& Waterhouse P.M. (1996). Barley yellow dwarf luteoviruses. Journal General Virology, 72, 1473-1477.

Sadeghi E., Dedryver C.H., Riault G., \& Gauthier J.P. (1997). Variation in transmission of two BYDV-MAV isolates by multiple clones of Rhopalosiphum padi L. European Journal of Plant Pathology, 103, 513-519. http://dx.doi.org/10.1023/A:1008673926685

Van Riessen H., Mask P., Fladrek K., Murphy J., \& Gazawy W. (1998). BYDV in small grains. Extension Plant Pathologist. Ups 7m23, ANR-1082.

Zadoks J., Chang T., \& Kozak C. (1974). A decimal code for growth stages of cereals. Weed research, 14, 415-421. http://dx.doi.org/10.1111/j.1365-3180.1974.tb01084.x

Table 1. Ability of aphid species to transmit BYDV on T. aestivum and H. vulgare

\begin{tabular}{|c|c|c|c|c|}
\hline \multirow{4}{*}{ The crop } & Aphid species & $\begin{array}{c}\text { Percentage of infected } \\
\text { plants to inoculated one }\end{array}$ & $\begin{array}{c}\text { Infection } \\
\text { percentage }\end{array}$ & Inoculation period \\
\hline \multirow{4}{*}{ T. aestivum } & Schizaphis gramineum & 13 of 30 & $43.5 \%$ & 17 \\
\cline { 2 - 5 } & Rhopalosiphum padi & 22 of 30 & $73.4 \%$ & 9 \\
\cline { 2 - 5 } & Rhopalosiphum maidis & 8 of 30 & $26.6 \%$ & 16 \\
\cline { 2 - 5 } & Macrosiphum avenae & 15 of 30 & $50.0 \%$ & 7 \\
\hline \hline \multirow{3}{*}{ H. vulgare } & Schizaphis gramineum & 15 of 30 & $50.0 \%$ & 14 \\
\cline { 2 - 5 } & Rhopalosiphum padi & 30 of 30 & $100.0 \%$ & 6 \\
\cline { 2 - 5 } & Rhopalosiphum maidis & 11 of 30 & $36.7 \%$ & 12 \\
\cline { 2 - 5 } & Macrosiphum avenae & 18 of 30 & $60.0 \%$ & 6 \\
\hline
\end{tabular}


Table 2. Distribution percentage of BYDV in northern, middle, and southern Iraqi provinces for 2007-2008 grown season

\begin{tabular}{|c|c|c|c|c|c|c|c|c|c|}
\hline \multirow[b]{2}{*}{ Region } & \multirow[b]{2}{*}{ Province } & \multicolumn{2}{|c|}{$\begin{array}{l}\text { Number of } \\
\text { studied fields }\end{array}$} & \multicolumn{2}{|c|}{$\begin{array}{c}\text { Number of total } \\
\text { samples }\end{array}$} & \multicolumn{2}{|c|}{$\begin{array}{c}\text { Number of } \\
\text { infected samples }\end{array}$} & \multicolumn{2}{|c|}{$\begin{array}{c}\text { Percentage of } \\
\text { infection }\end{array}$} \\
\hline & & $\begin{array}{l}-1 \\
0 \\
0 \\
0 \\
\vdots \\
\vdots \\
\vdots\end{array}$ & $\begin{array}{c}\nwarrow \\
\vdots \\
\vdots \\
00 \\
\vdots \\
0 \\
0\end{array}$ & 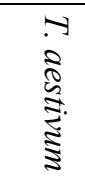 & 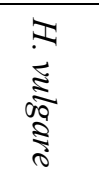 & 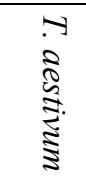 & 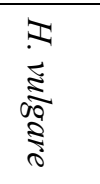 & 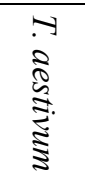 & $\begin{array}{c}\mathbb{Z} \\
\vdots \\
\vdots \\
0 \\
\vdots \\
\vdots \\
0\end{array}$ \\
\hline \multirow{9}{*}{ 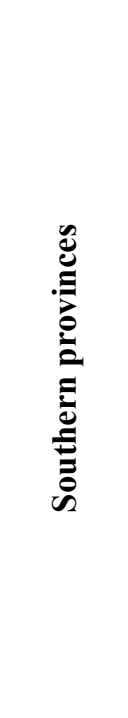 } & Basra & 5 & 6 & 250 & 300 & 0 & 0 & $\mathbf{0}$ & $\mathbf{0}$ \\
\hline & Missan & 5 & 6 & 250 & 300 & 0 & 0 & $\mathbf{0}$ & $\mathbf{0}$ \\
\hline & Thi-Qar & 5 & 6 & 250 & 300 & 0 & 0 & $\mathbf{0}$ & $\mathbf{0}$ \\
\hline & Wasit & 5 & 8 & 250 & 400 & 7 & 13 & 1.6 & 2.3 \\
\hline & Al-Muthanna & 3 & 4 & 150 & 200 & 0 & 0 & $\mathbf{0}$ & $\mathbf{0}$ \\
\hline & Al-Qadissiya & 3 & 4 & 150 & 200 & 0 & 0 & $\mathbf{0}$ & $\mathbf{0}$ \\
\hline & Babylon & 6 & 8 & 300 & 400 & 9 & 12 & 1.7 & 1.8 \\
\hline & Najaf & 5 & 6 & 250 & 300 & 10 & 14 & 1.6 & 2.4 \\
\hline & Karbala & 3 & 4 & 150 & 200 & 4 & 9 & 2 & 2.5 \\
\hline \multirow{4}{*}{ 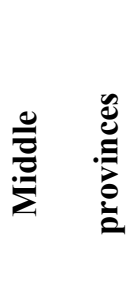 } & Baghdad & 6 & 7 & 300 & 350 & 19 & 29 & 4.4 & 5.2 \\
\hline & Dayalah & 5 & 7 & 250 & 350 & 8 & 15 & 2.8 & 5.2 \\
\hline & Anbar & 5 & 6 & 250 & 300 & 3 & 8 & $\mathbf{0}$ & 1.4 \\
\hline & Salah El-din & 6 & 7 & 300 & 350 & 9 & 12 & 3.4 & 3.7 \\
\hline \multirow{5}{*}{ 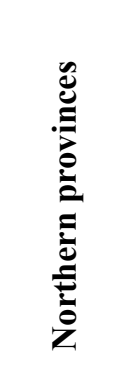 } & Ta'amim & 5 & 6 & 250 & 300 & 13 & 21 & 4 & 3.7 \\
\hline & Sulaimaniya & 12 & 13 & 600 & 650 & 18 & 29 & 3 & 4.8 \\
\hline & Erbil & 12 & 15 & 600 & 750 & 44 & 71 & 4.7 & 6.8 \\
\hline & Nineveh & 16 & 20 & 800 & 1000 & 87 & 189 & 11.5 & 14.4 \\
\hline & Dohuk & 10 & 14 & 500 & 700 & 34 & 65 & 5 & 8.3 \\
\hline
\end{tabular}


Table 3. Distribution percentage of BYDV in northern, middle, and southern Iraqi provinces for 2008-2009 grown season

\begin{tabular}{|c|c|c|c|c|c|c|c|c|c|}
\hline \multirow[b]{2}{*}{ Region } & \multirow[b]{2}{*}{ Province } & \multicolumn{2}{|c|}{$\begin{array}{c}\text { Number of } \\
\text { studied fields }\end{array}$} & \multicolumn{2}{|c|}{$\begin{array}{c}\text { Number of total } \\
\text { samples }\end{array}$} & \multicolumn{2}{|c|}{$\begin{array}{c}\text { Number of } \\
\text { infected samples }\end{array}$} & \multicolumn{2}{|c|}{$\begin{array}{c}\text { Percentage of } \\
\text { infection }\end{array}$} \\
\hline & & $\begin{array}{l}-1 \\
0 \\
0 \\
0 \\
\vdots \\
\vdots \\
\vdots\end{array}$ & $\begin{array}{c}\pi \\
\vdots \\
\vdots \\
00 \\
0 \\
0 \\
0\end{array}$ & $\begin{array}{l}-1 \\
0 \\
0 \\
0 \\
\vdots \\
\vdots \\
\vdots\end{array}$ & $\begin{array}{c}7 \\
\vdots \\
\vdots \\
0 \\
\vdots \\
0 \\
0\end{array}$ & 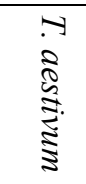 & $\begin{array}{c}\pi \\
\vdots \\
\vdots \\
00 \\
\vdots \\
0\end{array}$ & 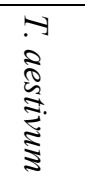 & $\begin{array}{c}\pi \\
\vdots \\
\vdots \\
0 \\
0 \\
0 \\
0\end{array}$ \\
\hline \multirow{9}{*}{ 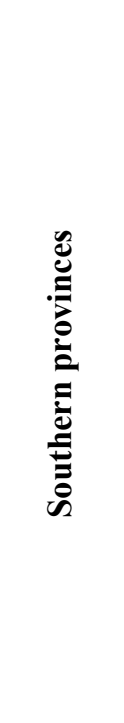 } & Basra & 3 & 4 & 150 & 200 & 0 & 0 & $\mathbf{0}$ & $\mathbf{0}$ \\
\hline & Missan & 4 & 6 & 200 & 300 & 0 & 0 & 0 & 0 \\
\hline & Thi-Qar & 5 & 6 & 250 & 300 & 0 & 0 & 0 & 0 \\
\hline & Wasit & 6 & 7 & 300 & 350 & 10 & 16 & 3.4 & 4.6 \\
\hline & Al-Muthanna & 3 & 4 & 150 & 200 & 0 & 0 & $\mathbf{0}$ & $\mathbf{0}$ \\
\hline & Al-Qadissiya & 2 & 4 & 100 & 200 & 3 & 7 & 3 & 3.5 \\
\hline & Babylon & 5 & 7 & 250 & 350 & 10 & 17 & 4 & 4.9 \\
\hline & Najaf & 5 & 7 & 250 & 350 & 13 & 20 & 5.2 & 5.7 \\
\hline & Karbala & 4 & 5 & 200 & 250 & 8 & 12 & 4 & 4.8 \\
\hline \multirow{4}{*}{ 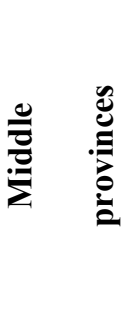 } & Baghdad & 7 & 9 & 350 & 450 & 30 & 44 & 8.5 & 9.8 \\
\hline & Dayalah & 4 & 7 & 200 & 350 & 13 & 25 & 6.5 & 7.2 \\
\hline & Anbar & 4 & 8 & 200 & 400 & 4 & 17 & 2 & 4.3 \\
\hline & Salah El-din & 6 & 8 & 300 & 400 & 16 & 26 & 5.4 & 6.8 \\
\hline \multirow{5}{*}{ 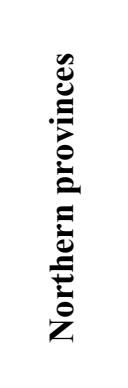 } & Ta'amim & 6 & 8 & 300 & 400 & 19 & 25 & 6.4 & 6.3 \\
\hline & Sulaimaniya & 10 & 12 & 500 & 600 & 31 & 43 & 6.2 & 7.2 \\
\hline & Erbil & 10 & 15 & 500 & 750 & 52 & 88 & 10.5 & 11.8 \\
\hline & Nineveh & 14 & 21 & 700 & 1050 & 122 & 252 & 17.5 & 24 \\
\hline & Dohuk & 9 & 12 & 450 & 600 & 55 & 52 & 12.3 & 13.7 \\
\hline
\end{tabular}


Table 4. Detection of secondary hosts for BYDV using TBIA test

\begin{tabular}{|c|c|c|c|}
\hline Name of the host & $\begin{array}{c}\text { Number of } \\
\text { total samples }\end{array}$ & $\begin{array}{c}\text { Number of positive } \\
\text { reacted samples }\end{array}$ & $\begin{array}{l}\text { Percentage } \\
\text { of infection }\end{array}$ \\
\hline Phragmites communis & 35 & 19 & 54.3 \\
\hline Avena fatua & 63 & 42 & 66.7 \\
\hline Lolium rigidum & 59 & 29 & 49.2 \\
\hline L. temulentum & 50 & 27 & 54 \\
\hline Cynodon dactylon & 32 & 10 & 31.3 \\
\hline Phalaris minor & 30 & 8 & 26.7 \\
\hline Slibium marianum & 20 & 0 & 0 \\
\hline Cyperus rotundus & 25 & 10 & 40 \\
\hline Beta Vulgaris & 30 & 0 & 0 \\
\hline Raphanus raphanis & 30 & 0 & 0 \\
\hline Malva parrioflora & 30 & 0 & 0 \\
\hline Militotus indicus & 30 & 0 & 0 \\
\hline Lipidium draba & 29 & 0 & 0 \\
\hline Carthamus oxycath & 25 & 0 & 0 \\
\hline Sinapsis arvensis & 23 & 0 & 0 \\
\hline Aegilops Lorenti & 40 & 12 & 30 \\
\hline Hordeum glaucum & 37 & 21 & 56.8 \\
\hline Convolvulus arvensis & 33 & 0 & 0 \\
\hline Cephalaria syriaca & 25 & 0 & 0 \\
\hline Ammi majus & 25 & 0 & 0 \\
\hline Zea mays & 27 & 18 & 66.7 \\
\hline Sorghum halepense & 32 & 15 & 46.9 \\
\hline Solanum nigrum & 25 & 0 & 0 \\
\hline Vicia angustifolia & 29 & 0 & 0 \\
\hline Polypogon monspeliensis & 32 & 0 & 0 \\
\hline Rumex dentatus & 25 & 0 & 0 \\
\hline Glycyrrhiza glabra & 21 & 0 & 0 \\
\hline Amarantnus blitoides & 30 & 0 & 0 \\
\hline Logonychium farctum & 29 & 0 & 0 \\
\hline Cynanchum acutum & 35 & 0 & 0 \\
\hline Bromus tectorum & 38 & 14 & 36.8 \\
\hline
\end{tabular}



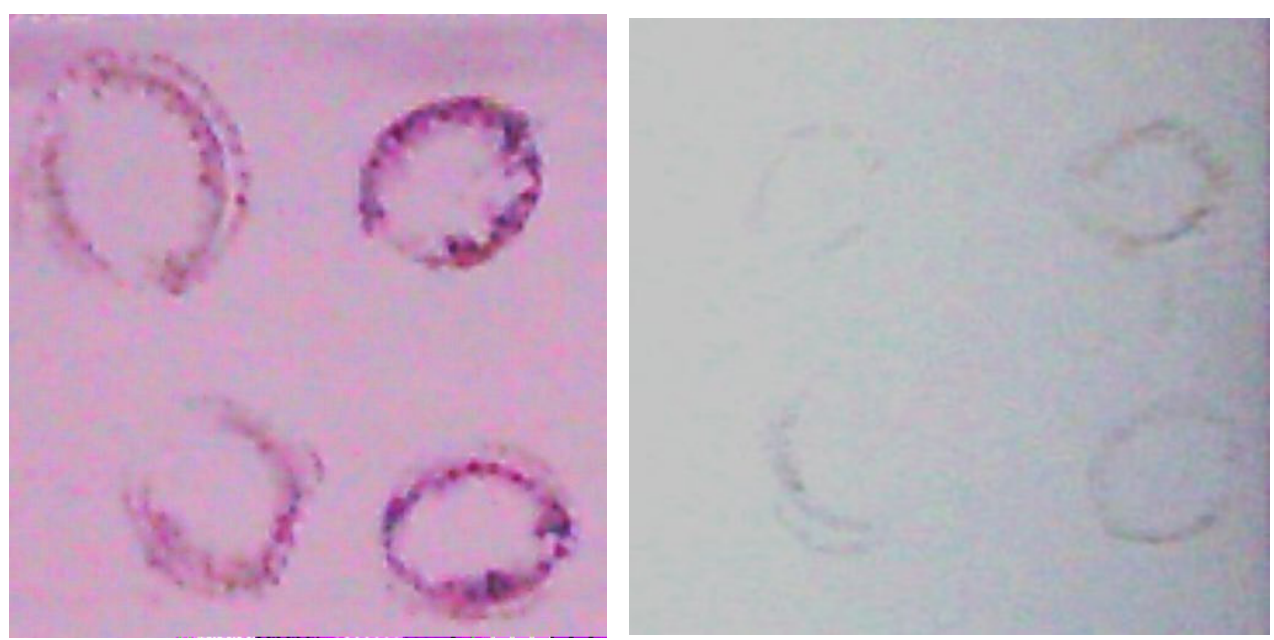

Figure 1. Tissue blot of cross-section of wheat (right) and barley (left) stem infected with Barley yellow dwarf virus (BYDV), on nitrocellulose membrane reacted with anti-BYDV polyclonal antibodies. The reactions were visualized by alkaline phosphatase conjugated to goat anti-rabbit immunoglobulins-G antibodies 